\title{
PENGARUH MODEL PEMBELAJARAN QUANTUM BERBASIS PENDEKATAN SAINTIFIK TERHADAP AKTIVITAS BELAJAR DAN HASIL BELAJAR IPA PADA SISWA KELAS IV GUGUS XIII KECAMATAN BULELENG
}

\author{
N.K. Purniwantini ${ }^{1}$, I.B.P. Arnyana ${ }^{2}$, I.W.Suastra ${ }^{3}$ \\ ${ }^{123}$ Program Studi Pendidikan Dasar \\ Universitas Pendidikan Ganesha \\ Singaraja, Indonesia \\ e-mail: purniwantini71@gmail.com ${ }^{1}$, putu.arnyana@undiksha.ac.id ${ }^{2}$, \\ iwsuastra@undiksha.ac.id ${ }^{3}$
}

\begin{abstract}
Abstrak
Penelitian ini bertujuan untuk mengetahui pengaruh model pembelajaran Quantum berbasis pendekatan saintifik terhadap aktivitas belajar dan hasil belajar IPA pada siswa kelas IV SD di Gugus XIII Kecamatan Buleleng. Rancangan eksperimen yang digunakan adalah rancangan non-equivalent posttest only control grup design. Populasi dalam penelitian ini 186 siswa kelas IV SD di Gugus XIII Kecamatan Buleleng. Dari 186 populasi siswa, 64 siswa ditetapkan sebagai sampel. Data aktivitas, dikumpulkan dengan lembar observasi, sedangkan data hasil belajar IPA siswa dikumpulkan dengan tes objektif. Teknik analisis data yang digunakan dalam penelitian ini adalah Manova. Hasil penelitian menunjukkan bahwa: 1) Terdapat perbedaan aktivitas belajar siswa antara siswa yang dibelajarkan menggunakan model pembelajaran Quantum berbasis pendekatan saintifik dengan siswa yang dibelajarkan menggunakan pendekatan saintifik. 2) Terdapat perbedaan hasil belajar IPA siswa antara siswa yang dibelajarkan menggunakan model pembelajaran Quantum berbasis pendekatan saintifik dengan siswa yang dibelajarkan menggunakan pendekatan saintifik 3) Terdapat perbedaan secara simultan aktivitas belajar dan hasil belajar IPA siswa antara siswa yang dibelajarkan menggunakan model pembelajaran Quantum berbasis pendekatan saintifik dengan siswa yang dibelajarkan menggunakan pendekatan saintifik. Jadi, dapat disimpulkan bahwa terdapat pengaruh model pembelajaran Quantum berbasis pendekatan saintifik terhadap aktivitas belajar dan hasil belajar IPA pada siswa kelas IV di Gugus XIII Kecamatan Buleleng
\end{abstract}

Kata Kunci : Aktivitas; Hasil Belajar IPA; Quantum Berbasis Saintifik

\section{Abstract}

This study aims to determine the effect of scientific based Quantum learning model on learning activities and science learning approach outcomes in $4^{\text {th }}$ grade students of SD Gugus XIII Buleleng Regency. This research is a quasi experimental research with design used is non-equivalent posttest only control of group design. The population of this study were 186 students. For those 186 students, there were 64 students assigned as samples. Learning activity data were collected by observation sheet, while data of science learning result were collected by objective test. Data analysis technique used in this research is Manova. The results showed that: 1) There was a difference of learning activity between students who were taught scientific based Quantum learning model on learning with scientific approach on the learning of science class $4^{\text {th }}$ of SD Gugus XIII Buleleng Regency, 2) there was difference of science achiement between students which is taught by scientific based Quantum learning model with scientific approach on science class $4^{\text {th }}$ of SD Gugus XIII Buleleng Regency, 3) there are differences simultaneously learning activities and science achiement between students who are taught by scientific based Quantum learning model with the scientific approach of science class $4^{\text {th }}$ of SD Gugus XIII Buleleng Regency.

Keywords : Activities; The Achiement Of Sience Studies; Quantum Base Of Saintifik 


\section{PENDAHULUAN}

Pendidikan di era globalisasi ini merupakan aspek yang terpenting untuk dimiliki. Pendidikan berfungsi untuk mengembangkan kemampuan dan membentuk watak serta peradaban bangsa yang bermartabat dalam rangka mencerdaskan kehidupan bangsa. Dengan Sistem pendidikan yang baik, akan muncul generasi penerus bangsa yang berkualitas, dan mampu menyesuaikan diri untuk bermasyarakat, berbangsa dan bernegara (Azarudin,2015) Pernyataan tersebut membuktikan bahwa usaha mencapai citacita luhur bangsa dapat diraih melalui pendidikan.

Pendidikan adalah usaha sadar dan terencana untuk mewujudkan suasana belajar dan proses pembelajaran sehingga peserta didik secara aktif megembangkan potensi dirinya. Dalam Proses pembelajaran bukanlah merupakan kegiatan yang tunggal, tetapi banyak faktor yang berkontribusi dan berinteraksi di dalamnya. Salah satu nya adalah aktivitas belajar. Aktivitas belajar merupakan hal yang penting dalam proses belajar mengajar yang dapat berpengaruh pada hasil belajar anak. Menurut Aswan (2015:19) Aktivias siswa dalam belajar merupakan persoalan penting dan mendasar yang harus dipahami, disadari, dan dikembangkan oleh guru dalam proses pembelajaran. Seorang guru dituntut untuk dapat merancang kegiatan pembelajaran yang memungkinkan siswa melakukan kegiatan secara aktif, baik fisik maupun mental. Keterlibatan aktivitas sangat penting karena hampir tidak pernah terjadi proses belajar tanpa adanya aktivitas belajar siswa dalam belajar. Aktivitas belajar yang tinggi dapat berpegaruh terhadap hasil belajar anak. Aktivitas belajar ditandai oleh adanya keterlibatan secara optimal baik intelektual, emosi, dan fisik.

IPA meliputi tiga cakupan yaitu sebagai produk, IPA sebagai proses, dan IPA sebagai sarana pengembangan sikap ilmiah (Dewi, 2013). Sebagai produk IPA adalah kumpulan hasil kegiatan emperik dan kegiatan analitik yang meliputi fakta, konsep, prinsip, prosedur, teori, dan hukum. Sedangkan IPA sebagai proses mengandung pengertian cara berfikir dan bertindak untuk menghadapi atau merespon masalah-masalah yang ada dilingkungan. Ini berarti tujuan pembelajaran IPA di SD di samping untuk mengembangkan pengetahuan dan pemahaman konsepkonsep IPA juga mengembangkan ketrampilan proses untuk menyelidiki alam sekitar. Berdasarkan hal tersebut dalam pembelajaran guru harus mampu menjadi fasilitator bagi siswa, mampu memanfaatkan dan mengunakan modelmodel pembelajaran yang inovatif sehingga siswa memiliki motivasi untuk mengikuti pembelajaran secara aktif dan menyenangkan serta mencapai hasil yang maksimal.

Pada kenyataannya, mata pelajaran IPA menjadi mata pelajaran yang dianggap sulit bagi sebagain siswa. $\mathrm{Hal}$ ini dikarenakan lemahnya pelaksanaan proses pembelajaran yang diterapkan oleh guru. Penyampaian pelajaran IPA masih berpusat pada guru. Sebagain besar guru belum mampu merancang dan menerapkan berbagai metode, pendekatan, strategi, dan model pembelajaran yang inovatif yang nantinya dapat memotivasi aktivitas belajar dan hasil belajar siswa.

Rendahnya hasil belajar IPA dibuktikan dari hasil survey yang dilakukan OECD (Organization for Economic Cooperation and Development) dalam bentuk PISA (Programme for International Student Assessment). Pada tahun 2018. Negara Indonesia berada peringkat ke-71 dari 78 negara dengan skor 396 (OECD, 2019).) Selain itu dari hasil observasi dan wawancara dibeberapa SD Gugus XIII Kecamatan Buleleng menunjukkan bahwa rata-rata hasil belajar IPA yang diperoleh masih belum optimal.

Dari hasil PISA, observasi, dan wawancara dibeberapa SD Gugus XIII Kecamatan Buleleng tersebut jelas diperlukan suatu perubahan dalam pendidikan di Indonesia dengan 
menerapkan suatu model pembelajaran. Adapun dalam penelitian ini model pembelajaran yang diharapkan mampu meningkatkan aktivitas belajar dan hasil belajar IPA siswa adalah Model pembelajaran Quantum berbasis pendekatan saintifik.

Model Quantum berbasis pendekatan saintifik adalah sebuah model yang berfokus pada hubungan dinamis dalam lingkungan kelas interaksi yang mendirikan landasan dan kerangka untuk belajar. Pembelajaran Quantum berbasis pendekatan saintifik memberikan kesempatan kepada siswa untuk mengaitkan segala interaksi dan perbedaan dalam memaksimalkan momen belajar. Proses pembelajaran berlangsung alamiah dalam bentuk kegiatan siswa bekerja dan mengalami sendiri, bukan transfer pengetahuan dari guru ke siswa. Dengan penerapan model pembelajaran Quantum berbasis pendekatan saintifik dapat memberikan peluang kepada siswa untuk membuat hubungan antara pengetahuan yang dimilikinya dengan penerapan dalam kehidupan sehari-hari mereka secara lebih tajam sehingga siswa akan terlibat aktif dalam pembelajaran serta dapat membentuk pemahaman yang maksimal dan dapat meningkatkan hasil belajar siswa khususnya pada pembelajaran IPA.

Langkah dari Model Pembelajaran Quantum berbasis pendekatan Saintifik adalah 1)Tumbuhkan yaitu menyiapkan mental siswa baik pisik dan phisikis, 2) Alami (menanya, mengamati) yaitu memberikan beberapa pertanyaan terkait dengan materi, 3) Namai (mengorganisasi) yaitu mencari sumber-sumber informasi, 4) Demontrasi (mengasosiasi) yaitu melakukan percobaan/eksperimen dalam kelompok, 5) Ulangi (mengkomunikasikan) mengevaluasi, 6) Rayakan memberikan pengakuan dan penghargaan.

Pemilihan solusi ini juga didukung dari beberapa hasil jurnal penelitian antara lain penelitian yang berjudul Pengaruh Pembelajaran Kuantum Terhadap Hasil Belajar IPA Siswa SD Kelas V Ditinjau dari Minat Outdoor oleh Gede Meta Adnyana
(2019), dan Penelitian yang dilakukan oleh Padmarani Sudewi Putri pada tahun 2018 yang berjudul Pengaruh Model Pembelajaran Tandur Terhadap Motivasi Belajar dan Hasil Belajar IPA Siswa Kelas V Tahun Ajaran 2017/2018 di Gugus IV Kecamatan Sukasada Singaraja. Hasil penelitian pertama menunjukkan bahwa terdapat perbedaan secara signifikan hasil belajar siswa dengan pembelajaran Kuantum dengan siswa yang mengikuti pembelajaran secara langsung. Dan hasil penelitian kedua menunjukkan bahwa terdapat perbedaan motivasi belajar siswa antara siswa yang dibelajarkan menggunakan model pembelajaran TANDUR dengan siswa yang dibelajarkan menggunakan model pembelajaran konvensional pada siswa kelas IV di Gugus IV Kecamatan Sukasada.

Berdasarkan uraian latar belakang tersebut, dibutuhkan pembuktian melalui eksperimen mengenai "Pengaruh Model Pembelajaran Quantum Berbasis Pendekatan Saintifik Terhadap Aktivitas belajar dan Hasil Belajar IPA Pada Siswa Kelas IV SD Gugus XIII Kecamatan Buleleng".

\section{METODE}

Penelitian ini dilaksanakan pada kelas IV DI GUGUS XIII Kecamatan Buleleng. Jenis penelitian yang dilakukkan adalah penelitian eksperimen. Mengingat tidak semua variable dan kondisi eksperimen dapat diatur dan dikontrol secara ketat, maka penelitian ini dikatagorikan penelitian eksperimen semu (quasi experiment), Rancangan penelitian yang digunakan adalah rancangan nonequivalent posttest only control group design (Dantes,2012). Dengan Desain eksperimen yang digunakan adalah desain group factorial $2 \times 2$. Penelitian ini terdiri dari dua variabel pokok. yakni variable bebas, dan variable terikat. Variabel bebas dalam penelitian ini adalah model pembelajaran Quantum berbasis saintifik dan pembelajaran saintik sedangkan variable terikatnya adalah aktivitas dan hasil belajar. 
Populasi yang digunakan dalam penelitian ini adalah semua siswa kelas IV Sekolah Dasar Gugus XIII Kecamatan Buleleng yang terdiri dari 6 Sekolah Dasar dengan jumlah siswa sebanyak 186 siswa. Pengambilan sampel pada penelitian ini menggunakan teknik simple random sampling.Teknik random sampling ini digunakan karena anggota populasi relative homogen (Sugiono, 2010). Kelas yang digunakan sebagai sampel, terlebih dahulu dilakukan uji kesetaraan, dengan menggunakan uji analisis varians satu jalur (ANAVA, A).

Setelah uji kesetaraan dilakukan, selanjutnya menentukan kelas eksperimen dan kelas control. Berdasarkan random sampling yang dilakukan, maka ditetapkan SDN 1 Baktiseraga ( Kelas IVB) dengan jumlah siswa 34 orang sebagai kelas ekperimen, dan SD Mutiara (Kelas IV B) dengan jumlah siswa 30 orang sebagai kelas control.

Dalam penelitian ini, data yang dikumpulkan adalah data mengenai aktivitas belajar dan hasil belajar IPA siswa kelas IV SD. Untuk mengumpulkan data aktivitas belajar siswa digunakan lembar observasi dengan 6 indikator. Yang memiliki skor berkisar antara 1 sampai 3 . Sedangkan data hasil belajar dikumpulkan dengan menggunakan metode tes. Tes yang digunakan dalam penelitian ini adalah tes obyektif dengan jumlah butir soal 40 yang terdiri empat pilihan. Untuk satu soal jika siswa menjawab benar diberi skor 1 dan jika siswa menjawab salah diberi skor 0 .

Setelah data terkumpul, dilakukan analisis data. Ada 3 tahap dalam menganalisis data dalam penelitian ini, yakni : (1) deskripsi data, (2) pengujian persyaratan analisis, dan (3) pengujian hipotesis.

Data yang sudah dikumpulkan ditabulasi rerata dan simpangan baku menyangkut data aktivitas belajar siswa dan hasil belajar siswa. Analisis statistik yang digunakan untuk menguji hipotesis adalah dengan menggunakan MANOVA. Pengujian hipotesis dilakukan dengan menggunakan bantuan program SPSS Windows 17.0 pada taraf signifikansi $5 \%$

\section{HASIL DAN PEMBAHASAN}

Objek dalam penelitian ini adalah aktivitas dan hasil belajar IPA sebagai hasil perlakuan antara pembelajaran dengan model pembelajaran quantum berbasis saintifik dan pembelajaran dengan berpendekatan saintifik. Analisis statistik yang digunakan untuk menguji hipotesis tersebut adalah dengan menggunakan MANOVA. Adapun data dalam penelitian ini dikelompokkan menjadi:

1) aktivitas belajar siswa yang mengikuti model pembelajaran quantum berbasis pendekatan saintifik, 2) hasil belajar IPA siswa yang mengikuti pembelajaran dengan model pembelajaran quantum berbasis pendekatan saintifik, 3) aktivitas belajar siswa yang mengikuti pembelajaran dengan pendekatan saintifik, 4) hasil belajar IPA siswa yang mengikuti pembelajaran dengan pendekatan saintifik.

Dari kelompok-kelompok data tersebut akan dicari tendensi data, meliputi mean $(\mathrm{X})$, median (Me), modus (Mo), standar deviasi (SD), varians, rentangan, skor maksimum, dan skor minimum. Analisis tersebut didasarkan pada skor rerata ideal (Mi) dan simpangan baku ideal (SDi) Setelah $\mathrm{Mi}$ dan SDi diketahui, langkah selanjutnya adalah mensubstitusikan nilai $\mathrm{Mi}$ dan SDi ke dalam tabel konversi berdasarkan penilaian acuan patokan. Perhitungan kelompok data aktivitas dan hasil belajar dapat dilihat pada tabel 1 berikut: 
Tabel 1. Rekapitulasi Hasil Perhitungan Skor Aktivitas Belajar dan Hasil Belajar IPA

\begin{tabular}{|c|c|c|c|c|}
\hline Statistik & $A_{1} Y_{1}$ & $A_{1} Y_{2}$ & $\mathrm{~A}_{2} \mathrm{Y}_{1}$ & $\mathrm{~A}_{2} \mathrm{Y}_{2}$ \\
\hline $\mathrm{N}$ & 34 & 34 & 30 & 30 \\
\hline Mean & 14,41 & 34,97 & 12 & 29,80 \\
\hline Median & 14 & 35 & 12 & 29,50 \\
\hline Modus & 13 & 35 & 13 & 32 \\
\hline Standar Deviasi & 2,12 & 2,36 & 2,55 & 2,85 \\
\hline Varians & 4,49 & 5,36 & 6,48 & 8,09 \\
\hline Rentangan & 9 & 9 & 10 & 10 \\
\hline Skor Minimum & 9 & 30 & 7 & 25 \\
\hline Skor Maksimum & 18 & 39 & 17 & 35 \\
\hline Jumlah & 490 & 1189 & 360 & 894 \\
\hline
\end{tabular}

Keterangan:

$\mathrm{A}_{1} \mathrm{Y}_{1}=$ Aktivitas belajar siswa yang mengikuti model pembelajaran quantum berbasis pendekatan saintifik

$A_{1} Y_{2}=$ Hasil belajar IPA siswa yang mengikuti model pembelajaran quantum berbasis pendekatan saintifik

$\mathrm{A}_{2} \mathrm{Y}_{1}=$ Aktivitas belajar siswa yang mengikuti pembelajaran dengan pendekatan saintifik.

$\mathrm{A}_{2} \mathrm{Y}_{2}=$ Hasil belajar IPA siswa yang mengikuti pembelajaran dengan pendekatan saintifik.

Berdasarkan tabel di atas rata-rata skor aktivitas belajar dan hasil belajar IPA, yang dibelajarkan dengan model pembelajaran Quantum berbasis saintifk lebih besar dibandingkan siswa yang mengikuti pembelajaran dengan pendekatan saintifik.

Sebelum melakukan uji hipotesis, terlebih dahulu dilakukan analisis uji prasyarat yang meliputi uji normalitas sebaran data, uji homogenitas varians, uji korelasi antar variable terikat. Hasil pengujian normalitas data menggunakan statistik Kolmogiorov-Smirnov menunjukkan bahwa nilai-nilai statistik yang diperoleh memiliki angka signifikansi lebih besar dari 0.05. Hal ini menunjukkan bahwa aktivitas belajar dan hasil belajar siswa berdistribusi normal. Hasil pengujian homogenitas varian mengunakan Levene's Test of Equality of
Error Variances untuk kelompok model pembelajaran menunjukkan angka-angka signifikansi statistik Levene lebih besar dari $\alpha=0,05$. Hal ini menunjukkan bahwa varian antar model pembelajaran adalah homogen. Hasil pengujian homogenitas matrik varian menggunakan uji Box's $M$ menunjukkan bahwa Box's $M$ memiliki nilai 0,531 dengan $\alpha=0,708$ dan lebih besar dari 0,05. Hal ini menunjukkan bahwa matriks varian-kovarians terhadap variabel aktivitas belajar dan hasil belajar IPA siswa adalah homogen.

Berdasarkan hasil uji prasyarat yang meliputi uji normalitas sebaran data, uji homogenitas varians dan uji korelasi antar variable terikat dapat disimpulkan bahwa data yang dipakai dalam penelitian ini dapat diteruskan untuk dipakai dalam pengujian hipotesis.Terdapat tiga hipotesis yang diujikan dalam penelitian ini, meliputi :

1. Terdapat pengaruh aktivitas belajar antara kelompok siswa yang mengikuti model pembelajaran quantum berbasis pendekatan saintifik dengan kelompok siswa yang mengikuti pembelajaran dengan pendekatan saintifik.

2. Terdapat pengaruh hasil belajar IPA antara kelompok siswa yang mengikuti model pembelajaran quantum berbasis pendekatan saintifik dengan kelompok siswa yang mengikuti pembelajaran dengan pendekatan saintifik.

3. Terdapat pengaruh aktivitas belajar dan hasil belajar IPA secara simultan antara kelompok siswa yang mengikuti model 
pembelajaran quantum berbasis pendekatan saintifik dengan kelompok siswa yang mengikuti pembelajaran dengan pendekatan saintifik.
Berdasarkan Uji hipotesis yang dilakukan dengan menggunakan MANOVA pada taraf signifikansi 0,05., didapat hasil pengujian hipotesis yang tersaji pada tabel 2 berikut

Tabel 2. Hasil Pengujian Hipotesis

\begin{tabular}{ll}
\hline Hipotesis & Hasil analisis \\
\hline Hipotesis 1 & $(\mathrm{~F}=17,094 ; \mathrm{p}<0,05)$ \\
Hipotesis 2 & $(\mathrm{F}=64,156 ; \mathrm{p}<0,05)$ \\
Hipotesis 3 & $(\mathrm{F}=33,304 ; \mathrm{p}<0,05)$ \\
\hline
\end{tabular}

Berdasarkan data pada tabel 2 dapat dijelaskan sebagai berikut.

Untuk pengujian hipotesis kesatu menunjukkan bahwa nilai sebesar 17,094 dengan taraf signifikansi $\alpha=0,05$, maka nilai signifikansi jauh lebih kecil daripada $\alpha$ sehingga $F$ signifikan. Hal ini berarti bahwa $\mathrm{H}_{0}$ ditolak dan menerima $\mathrm{H}_{1}$ yang menyatakan bahwa terdapat pengaruh aktivitas belajar antara kelompok siswa yang mengikuti model pembelajaran quantum berbasis pendekatan saintifik dengan kelompok siswa yang mengikuti pembelajaran dengan pendekatan saintifik pada siswa kelas IV di Gugus XIII Kecamatan Buleleng. Hal ini menunjukan bahwa model pembelajaran Quantum berbasis Saintifik lebih baik dalam meningkatkan aktivitas belajar siswa.

Hipotesis kedua berdasarkan tabel tersebut menunjukan nilai $F$ sebesar 64,156 dengan taraf signifikansi $\alpha=0,05$, maka nilai signifikansi lebih kecil daripada $\alpha$ sehingga $F$ signifikan. Hal ini berarti bahwa $\mathrm{H}_{0}$ ditolak dan menerima $\mathrm{H}_{1}$ yang menyatakan bahwa terdapat pengaruh hasil belajar IPA antara kelompok siswa yang mengikuti model pembelajaran quantum berbasis pendekatan saintifik dengan kelompok siswa yang mengikuti pembelajaran dengan pendekatan saintifik.

Hipotesis ketiga menunjukan bahwa nilai F untuk Pillai's Trace, Wilks' Lambda Hotelling's Trace, dan Roy's Largest Root sebesar 33,304 dengan nilai signifikansi 0,000 . Apabila ditetapkan taraf signifikansi $\alpha$
$=0,05$, maka nilai signifikansi jauh lebih kecil dari pada a sehingga $F$ signifikan. Hal ini berarti bahwa $\mathrm{H}_{0}$ ditolak dan menerima $\mathrm{H}_{1}$ yang menyatakan bahwa terdapat pengaruh aktivitas belajar dan hasil belajar IPA secara simultan antara kelompok siswa yang mengikuti model pembelajaran quantum berbasis pendekatan saintifik dengan kelompok siswa yang mengikuti pembelajaran dengan pendekatan saintifik.

Hakikat dari pembelajaran adalah guru harus sebagai fasilitator proses pembelajaran. Peran guru sangatlah penting, guru harus mampu memilih, merencanakan dan melaksanakan model pembelajaran yang inovatif yang nantinya dapat meningkatkan proses dan hasil belajar anak. Pendekatan saintifik yang saat ini digunakan walaupun sudah menunjukkan aktivitas belajar, namun belum maksimal. Hal ini karena guru hanya menggunaan pendekatan yang sama (saintifik) secara terus menerus dalam pembelajaran. Dampak yang dapat ditimbulkan adalah timbulnya kebosanan bagi siswa dalam proses pembelajaran. Untuk itu perlu kiranya seorang guru mengkolaborasikan pendekatan saintifik dengan model pembelajaran inovatif yang lain. Model Pembelajaran Quantum Berbasis Saintifik merupakan model pembelajaran inovatif dan bisa dijadikan alternatif guru dalam merencanakan dan melaksanakan proses pembelajaran dalam upaya untuk memperbaiki dan membangun 
semangat pada diri peserta didik dalam proses pembelajaran.

Pernyataan tersebut sejalan dengan, Gunarhadi, dkk (2014) yang menyatakan model pembelajaran Quantum memberikan ruang bagi siswa mengembangkan potensi melalui interaksi sosial dengan lingkungan. Sehingga tercipta pengalaman belajar yang bermakna bagi siswa. Kemudian berdiskusi dalam kegiatan berkelompok serta menyampaikan hasil diskusi kelompoknya ke teman yang lain. Secara keseluruhan, pembelajaran Quantum terlihat mampu meningkatkan partisipasti dan peran aktif siswa dalam belajar. Siswa tampak lebih bersemangat dan termotivasi dalam kegiatan pembelajaran. Sehingga dengan pembelajaran dengan model ini dapat membentuk pengetahuan IPA, memberi pengalaman yang bermakna bagi siswa.

Dalam model pembelajaran quantum berbasis saintifik siswa diajak untuk belajar lebih menyenangkan karena dalam pembelajaran menggunakan model pembelajaran Quantum berbasis saintifik, siswa aktif dalam pembelajaran secara fisik dan mental. Siswa tidak hanya menerima materi tetapi menemukan sendiri konsep melalui aktivitas belajar. Interaksi yang terjadi dalam Model Pembelajaran Quantum Berbasis Saintifik multi arah. Artinya interaksi dari siswa dengan siswa dalam bentuk aktivitas belajar kelompok, saling bertukar pendapat dan saling membagi tugas dalam kelompok. Sedangkan aktivitas guru dan siswa terjadi dalam bentuk guru mengadakan tanya jawab dan membimbing siswa dalam kerja kelompok, dan siswa menanyakan hal- hal yang kurang dimengerti. Aktivitas belajar siswa selama proses belajar mengajar merupakan salah satu indikator adanya keinginan siswa untuk belajar. Dalam model pembelajaran quantum berbasis saintifik, memiliki ciri yaitu pembelajaran siswa dibelajarkan dengan menjadi beberapa kelompok, siswa lebih aktif sedangkan guru hanya bertindak sebagai fasilitator dan motivator. Guru mengadakan evaluasi untuk mengetahui pemahaman materi siswa. Dan diakhir kegiatan guru akan memberikan penghargaan atau pengakuan bagi siswa yang aktivitas belajarnya tinggi dan hasil belajarnya terbaik. Penghargaan dan pengakuan menjadi hal penting, karena dapat meningkatkan motivasi dan aktivitas anak untuk belajar. Berdasarkan hal tersebut dapat disimpulkan bahwa model pembelajaran Qantum berbasis saintifik lebih efektif dalam meningkatkan aktivitas siswa, hal ini diperkuat oleh penelitian yang dilakukan oleh Gede Metta Adnyana (2019) yang berjudul Pengaruh Model Pembelajaran Kuantum Terhadap Hasil belajar IPA siswa SD Kelas V Ditinjau dari Minat Outdoor. Hasil penelitian tersebut menunjukan 1) Terdapat perbedaan yang signifikan hasil belajar IPA antara siswa yang mengikuti pembelajaran dengan model pembelajaran Kuantum dan siswa yang mengikuti pembelajaran langsung $(F A=24,189 ; p<0,05), 2)$ Terdapat pengaruh interaksi yang signifikan antara model pembelajaran Kuantum dan minat outdoor terhadap hasil belajar IPA siswa $(F A B=4,7 ; p>0,05)$, 3) Pada siswa yang memiliki minat outdoor tinggi, terdapat perbedaan signifikan hasil belajar IPA antara siswa yang mengikuti pembelajaran dengan model pembelajaran Kuantum dan siswa yang mengikuti pembelajaran langsung $(Q=6,06 ; p>0,05), 4)$ Pada siswa yang memiliki minat outdoor rendah, tidak terdapat perbedaan signifikan hasil belajar antara siswa yang mengikuti pembelajaran dengan model pembelajaran Kuantum dan siswa yang mengikuti pembelajaran langsung $(Q=2,35 ; p>0,05)$. Sejalan dengan penelitian tersebut Huda (2013) juga mengadakan penelitian yang berjudul Pengaruh Pembelajaran Quantum dalam Pembelajaran IPA Terhadap Keaktivan Belajar dan Penguasaan konsep Siswa kelas IV SDN 3 Pancor. Hasil penelitian menunjukkan bahwa 1) terdapat perbedaan secara signifikan keaktivan belajar siswa dengan pembelajaran Quantum dengan siswa yang mengikuti pembelajaran konvensional $(\mathrm{F}=$ $26,47 ; p<0,05), \quad 2)$ terdapat perbedaan secara signifikan penguasan konsep IPA antara siswa yang mengikuti pembelajaran 
Quantum dengan siswa yang mengikuti pembelajaran konvensional $(F=26,36$; $p<$ $0,05)$, 3) terdapat perbedaan secara signifikan keaktivan belajar dan penguasan konsep IPA siswa yang mengikuti pembelajaran Quantum dengan siswa yang mengikuti pembelajaran konvensional ( $\mathrm{F}=$ 26,$14 ; p<0,0,5$ ).

Hasil belajar IPA merupakan salah satu indikator untuk mengukur keberhasilan siswa dalam proses belajar IPA. Hasil belajar dikatakan baik apabila dalam diri siswa terjadi perubahan pada tiga bidang sesuai dengan tujuan taksonomi pendidikan dari Bloom yaitu kognitif, afektif, dan psikomotornya (Hosnan, 2014:10). Dalam belajar IPA terjadi proses berpikir dalam menyusun hubungan-hubungan antara bagian-bagian informasi yang diperoleh sebagai pengertian. Pada model pembelajaran Quantum berbasis pendekatan saintifik siswa diajak untuk membangun pengetahuannya sendiri, guru hanya sebagai fasilitator dan mediator siswa mendapat kebebasan dalam pemecahan masalah. Guru membimbing, dan mengarahkan siswa untuk menemukkan pemecahan. Pembelajaran yang melibatkan siswa secara aktif, baik aktif fisik dan mental, akan membantu dan memudahkan siswa dalam memahami sebuah konsep selama proses dan setelah proses pembelajaran.

Pembelajaran IPA adalah pembelajaran yang mengajarkan ilmu pengetahuan tentang gejala alam yang dituangkan berupa fakta, konsep, prinsip dan hukum yang teruji kebenarannya dan melalui suatu rangkaian kegiatan dalam metode ilmiah. Pada hakikatnya IPA meliputi tiga cakupan yaitu sebagai produk, IPA sebagai proses dan IPA sebagai sarana pengembangan sikap. Apabila pembelajar IPA dikaitkan dengan model pembelajaran Quantum berbasis saintifik maka model dengan pembelajaran ini akan mengajak siswa terlibat langsung dan aktif selama proses pembelajaran. Dalam model pembelajaran Quantum berbasis saintifik tidak hanya meningkatkan kemampuan intelektual siswa, juga mampu meningkatkan ketrampilan siswa lainnya. Ketrampilan yang penting dalam IPA dan mampu ditingkatkan dengan pembelajaran berpendekatan Quantum berbasis saintifik adalah ketrampilan proses sains siswa. Ketrampilan proses sains dalam model pembelajaran Quantum berbasis saintifk diperoleh siswa melalui percobaan untuk menemukan konsep. Dengan mengalami sendiri, siswa akan menemukan pengalaman belajar belajar yang lebih bermakna. Model pembelajaran Quantum berbasis saintifk mampu membantu siswa untuk lebih berfikir aktif, kreatif, dan bertanggung jawab terhadap tugas yang diberikan untuk menemukan cara pemecahan masalah sehingga menemukan hasil yang optimal. Hal ini diperkuat oleh penelitian yang dilakukan oleh Agus Supramono (2016) yang berjudul Pengaruh Model Pembelajaran Quantum (Quantum Teaching) Terhadap Hasil Belajar IPA Kelas III SD YPS Lawewu Kecamatan Nuha Kabupaten Luwu Timur. Hasil penelitian menunjukkan bahwa penerapan model pembelajaran Quantum di kelas III D mengalami peningkatan disetiap pertemuannya berdasarkan 6 aspek yang diamati yaitu Tumbuhkan, Alami, Namai, Demonstrasikan, Ulangi dan Rayakan. Hasil uji paired sample t-test menunjukkan $t$ hitung sebesar -11.568 pada derajat kebebasan (df) 25 dengan probabilitas (signifikansi) sebesar 0,000 $<0.05$, artinya $\mathrm{HO}$ ditolak dan $\mathrm{H} 1$ diterima. Jadi, terdapat perbedaan yang signifikan hasil belajar IPA siswa sebelum dan setelah diterapkan Quantum Teaching. Sejalan dengan penelitian tersebut Ratnadewi (2013) mengadakan penelitian yang berjudul "Pengaruh Model Pembelajaran Tandur Terhadap Hasil belajar IPA Pada Siswa Kelas V di Desa Anturan". Menunjukkan bahwa, rata-rata kelompok siswa yang dibelajarkan dengan menggunakan model pembelajaran TANDUR sebesar 23,50 sedangkan kelompok siswa yang dibelajarkan dengan pembelajaran konvensional rata-rata sebesar 12,63. Ini membuktikan bahwa model pembelajaran TANDUR berhasil. 
Aktivitas belajar dan hasil belajar memiliki keterkaitan satu dengan yang lainnya, artinya aktivitas siswa dalam proses pembelajaran akan mempengaruhi hasil belajarnya pula. Aktivitas belajar yang tinggi pada anak memiliki kecendrungan hasil belajar lebih baik. Model pembelajaran Quantum berbasis saintifik pada dasarnya menekankan pentingnya membangun pengetahuan peserta didik lewat keterlibatan aktif dalam proses pembelajaran. Guru hanya berperan sebagai fasilitator yang mengarahkan pembelajaran agar menjadi bermakna. Pembelajaran yang bermakna tentu berdampak pada hasil belajar siswa..

Dari banyak hasil penelitan dalam bidang pendidikan, siswa yang memiliki aktivitas belajar yang sangat tinggi terhadap pembelajaran cenderung memiliki hasil yang tinggi pula. Dalam pembelajarannya tidak hanya guru yang aktif dalam memfasilitasi siswa tetapi siswa juga aktif selama proses pembelajaran berlangsung. Siswa akan lebih aktif untuk membangun pengetahuannya sendiri melalui melalui pengamatan dan percobaan yag dilakukan. Dengan siswa melakukan aktivitas belajar yang tinggi, maka secara tidak langsung pengetahuan yang dipacu tersebut akan lebih lama tersimpan dalam memori siswa sehingga pada saat siswa diberikan tes hasil belajar, maka hasil tes akan sesuai dengan yang diharapkan.

Temuan dalam penelitian ini sejalan dengan hasil penellitian yang dilakukan oleh Padmarani Sudewi Putri ( 2018) menunjukkan bahwa 1) terdapat perbedaan motivasi belajar siswa antara siswa yang dibelajarkan menggunakan model pembelajaran Tandur dengan siswa yang dibelajarkan menggunakan model pembelajaran konvensional dengan hasil $F$ hitung 0,382 dengan signifikansi $<0,05,2,2$ ) terdapat perbedaan hasil belajar IPA siswa antara siswa yang dibelajarkan menggunakan model pembelajaran Tandur dengan siswa yang dibelajarkan dengan model pembelajaran konvensional dengan hasil $F$ hitung 0,039 dengan signifikansi $<0,05$. 3) terdapat perbedaan secara simultan motivasi belajar dan hasil belajar IPA siswa anatara siswa yang dibelajarkan menggunakan model pembelajaran TANDUR dengan siswa yang dibelajarkan dengan pembelajaran konvensional dengan hasil $F$ hitung 19,913 dengan signifikansi $<0,05$

\section{PENUTUP}

Berdasarkan hasil pengujian hipotesa dan pembahasan, dapat ditarik simpulan sebagai berikut.

1. Terdapat pengaruh aktivitas belajar antara siswa yang dibelajarkan dengan Model pembelajaran Quantum berbasis saintifik dengan pendekatan saintifik.

2. Terdapat perbedaan hasil belajar IPA antara siswa yang dibelajarkan dengan Model pembelajaran Quantum berbasis saintifik dengan pendekatan saintifik.

3. Terdapat perbedaan secara simultan aktivitas belajar dan hasil belajar IPA antara siswa yang dibelajarkan dengan Model pembelajaran Quantum berbasis saintifik dengan pendekatan saintifik.

Beberapa saran yang dikemukkan sehubungan dengan hasil yang diperoleh dalam penelitian ini adalah sebagai berikut;

1. Guru hendaknya mempelajari setiap detil model pembelajaran Quantum berbasis saintifik baik dari segi isi dan konteks, hal ini bertujuan agar guru memahami konsep dari model pembelajaran Quantum berbasis saintifk dalam penerapan proses belajar mengajar.

2. Kepada peneliti lain di sarankan untuk meneliti pengaruh model pembelajaran Quantum berbasis saintifk, pada muatan pelajaran yang lain.

\section{DAFTAR RUJUKAN}

Aswan, Z. 2015. Strategi Belajar Mengajar. Jakarta : Rineka Cipta.

Adnyana, Gede Metta. 2019. Pengaruh Model Pembelajaran Kuantum Terhadap Hasil Belajar IPA Siswa SD Kelas V Ditinjau dari Minat Outdoor. Jurnal Pendidikan dan Pembelajaran 
IPA Volume 9 (2). Tersedia http://ejournal-pascaundiksha.ac.id

Azarudin,S. 2015. Menyiapkan generasi Emas Indonesia Dengan Pendidikan Berkualitas. Bangka Belitung: Radar Bangka

Dantes. 2017. Desain Eksperimen dan Analisis Data. Singaraja: Undiksha Press.

Gunarhadi, Kassim, M., Sukor, A. S. 2014. "The Impact Of Quantum Teaching Strategy On Student Academic Achievements And Selfesteem In Inclusive Schools". Journal (diterbitkan). Malaysian Journal of Learning and Instruction: Vol. 11.

Hosnan, M.2014. Pendekatan Saintifik dan Kontekstual dalam Pembelajaran Abad 21 Kunci Sukses Implementasi Kurikulum 2013. Jakarta: Ghalia Indonesia.

Huda, N.2013. Pengaruh Pembelajaran Quantum dalam Pembelajaran IPA Terhadap Motivasi Belajar dan Penguasaan Konsep Siswa Kelas IV SDN 3 Pancor. e-Journal program Pascasarjana Universitas Pendidikan Ganesha Vol. 3. Tersedia pada http://ejournal.undiksha.ac.id

Kemendikbud. 2016. Peraturan Menteri Pendidikan dan Kebudayaan Nomor 22 Tahun 2016. Jakarta: Kementerian Pendidikan dan Kebuadayan RI.

Putri, Padmarani Sudewi. 2017. Pengaruh Model Pembelajaran Tandur terhadap Motivasi Belajar dan Hasil Belajar IPA Siswa kelas $V$ Tahun ajaran 2017/2018 di Gugus IV Kecamatan Sukasada Singaraja. Tesis (tidak diterbitkan). Singaraja: Universitas Pendidikan Ganesha.
Ratna, Dewi. 2013. Pengaruh Model Pembelajaran Tandur terhadap Hasil Belajar IPA Pada Siswa SD Kelas V di Gugus XIV Kecamatan Buleleng. Tesis(tidak diterbitkan). Singaraja: Universitas Pendidikan Ganesha.

Septiasasari, Ni Putu. 2020. Pengaruh Model Repciprocal teaching Berbasis Saintifik Terhadap Kemampuan Berfikir kritis dan Hasil Belajar IPA Kelas $V$. Jurnal Pendidikan Dasar Volume 4 (1). Tersedia http://ejournal-pascaundiksha.ac.id

Sugiono. 2010. Metode Penelitian Pendidikan Pendekatan Kuantitatif, Kualitatif, dan R\&D. Bandung: alfabeta.

Supramono, Agus 2016. Pengaruh Model Pembelajaran Quantum ( Quantum Teaching terhadap Hasil Belajar IPA Kelas III SD YPS Lawewu Kecamatan Nuha Kabupaten LuwuTimur. Tersedia pada Jurnal Nalar Pendidikan Volume 4 (2). Tersedia pada http:// medianeltti .com 